\title{
GAMBARAN PEMERIKSAAAN HAPUSAN DARAH TEPI DIFFCOUNT (SEL LIMFOSIT) PADA PENDERITA TBC DI PUSKESMAS KELAYAN TIMUR BANJARMASIN
}

\section{The Description of Examination Blood Smear Diffcount Analysis (Lymphocyte Cell) for patients with TBC at Puskesmas Kelayan Timur Banjarmasin}

\author{
Dina $^{1}$, Yudi Yahya ${ }^{1}$, Muhammad Zaini ${ }^{2}$ \\ ${ }^{1}$ Program Studi D-III Analis Kesehatan Politeknik Unggulan Kalimantan \\ ${ }^{2}$ Program Studi D-III Farmasi Politeknik Unggulan Kalimantan \\ Email: dina02di@gmail.com
}

\begin{abstract}
Tuberculosis (TB) is a infectious disease caused by Mycobacterium tuberculosis. TB treatment aims to prevent recurrence and break the chain of transmission and prevent bacterial resistance to anti-TB drugs. Tuberculosis can cause an increase in lymphocytes. Lymphocytosis in pulmonary TB occurs due to the activation of lymphocyte cells which play a role in cellular immunity to Mycobacterium tuberculosis. The purpose of this study was to analyze the percentage of lymphocyte cells of patients during their treatment at Kelayan Timur Health Center. This research used a descriptive qualitative with a diff count examination method. From the research which been done from 26 samples obtained lymphocytes $<20 \%$ (4\%), 20-40\% (65\%), and >40\% (31\%). Based on the research, it can be concluded that normal results are obtained on lymphocyte count after consuming Anti Tuberculosis Drugs after 6 months of treatment.
\end{abstract}

Keywords : Blood Smear, Lymphocyte Cell, TBC

\begin{abstract}
ABSTRAK
Tuberkulosis adalah penyakit menular yang disebabkan oleh bakteri Mycobacterium tuberculosis. Tujuan pengobatan TBC yaitu untuk menyembuhkan pasien,mencegah kematian,mencegah kekambuhan,memutuskan rantai penularan dan mencegah resistensi bakteri terhadap Obat Anti Tuberkulosis. Tuberkulosis dapat menyebabkan peningkatan limfosit. Limfositosis pada TB paru terjadi disebabkan aktivasi sel limfosit yang berperan dalam imunitas selular terhadap Mycobacterium tuberculosis. Penelitian ini bertujuan untuk mengetahui gambaran dan persentase sel limfosit penderita TBC yang menjalani pengobatan di Puskesmas Kelayan Timur. Jenis penelitian ini yaitu deskriptif kualitatif dengan metode pemeriksaan diffcount. Hasil penelitian menunjukkan dari 26 sampel didapatkan limfosit $<20 \%(4 \%), 20-40 \%(65 \%)$, dan $>40 \%(31 \%)$. Berdasarkan penelitian dapat disimpulkan bahwa didapatkan hasil normal pada jumlah limfosit setelah mengkonsummsi Obat Anti Tuberkulosis setelah 6 bulan pengobatan.
\end{abstract}

Kata Kunci : Hapusan Darah Tepi, Sel Limfosit, TBC 


\section{PENDAHULUAN}

Tuberkulosis disebabkan oleh bakteri Mycobacterium tuberculosis. Kuman tuberkulosis menyerang paru, tetapi dapat juga mengenai organ lain. Penyakit ini dapat menginfeksi dari laki-laki, wanita sampai anak-anak (Kemenkes, 2017). Pengobatan TB Paru menggunakan Obat Anti Tuberkulosis (OAT) yang dibagi menjadi 2 kelompok, yaitu pengobatan lini pertama dan pengobatan lini kedua. Pengobatan tuberkulosis pada lini pertama, yaitu rifampisin, isoniazid, etambutol, pirazinamid, stertomisin. Obat-obatan pada lini pertama ini memiliki efektivitas lebih tinggi dan toksisitas yang sedang, namun karena mempertimbangkan resistensi dan kontraindikasi pasien maka terdapat pengobatan tuberkulosis lini kedua, seperti anti biotik golongan fluoro kuinolon (siprofloksasin, levofloksasin, ofloksasin, etionamid, kanamisin, sikloserin, amikasin, kapreomisin dan paramino salisilat) (Azizah, 2018).

Puskesmas Kelayan Timur merupakan salah satu Puskesmas tergolong angka TBC tertinggi di kota Banjarmasin dengan jumlah kasus sebanyak 130 kasus (Dinkes, 2018).Limfosit merupakan sumber imunoglobulin yang penting dalam respon imun seluler tubuh, Fungsi utama limfosit untuk mengenali dan menghilangkan ancaman bagi tubu. Terdapat dua jenis limfosit yaitu limfosit B dan limfosit T. Limfosit tipe B memproduksi antibodi yang beredar dalam darah yang berhubungan dengan imunitas yang diperantarai oleh antibody (imunitas humoral). Limfosit $\mathrm{T}$ tidak memproduksi antibodi, sel ini secara langsung menghancurkan sel sasaran spesifiknya dengan mengeluarkan beragam zat kimia (Suciyani dkk, 2017).

Menurut penelitian Sri Herawati tentang Persentase Limfosit pada Penderita Tuberkulosis Paru di Rumah Sakit Arifin Achmad Pekanbaru tahun 2013 diperoleh hasil peningkatan jumlah limfosit $>40 \%$. OAT dapat meningkatkan kadar limfosit darah menjadi lebih tinggi dari batas normal. Hal ini guna meningkatkan pertahanan tubuh terhadap bakteri Mycobacterium tuberculosis. Peningkatan kadar limfosit menunjukkan proses penyembuhan

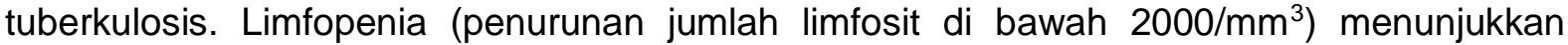
proses tuberkulosis aktif. Tuberkulosis yang aktif menyebabkan penurunan total limfosit $T$ dan Sel B total merupakan penanda pengobatan tuberkulosis berhasil, sehingga memperbaiki jumlah sel-sel tersebut menjadi normal (Rahmawati,2013). Tujuan penelitian ini adalah untuk mengetahui gambaran sel limfosit dan untuk mengetahui persentase sel limfosit penderita TBC di Puskesmas Kelayan Timur Banjarmasin.

\section{METODE PENELITIAN \\ Bahan}

Bahan yang digunakan adalah Pewarnaan Wright, buffer $\mathrm{pH} 6,4$, kapas alkohol $70 \%$, kapas kering, dan aquadest.

Alat

Alat yang digunakan adalah Spuit 3 cc, kaca objek, mikroskop, tabung EDTA, rak tabung, rak pengecatan, pipet tetes, tourniquet.

\section{Pengolahan Sampel}

Sampel darah diperoleh dari pasien TB paru yang menjalani pengobatan bulan ke-6. Sampel darah diambil dari vena mediana cubiti. darah diteteskan pada kaca objek kemudian dibuat hapusan darah dengan cara menggeser kaca objek dengan kemiringan $30^{\circ}$ sampai $45^{\circ}$. Biarkan sediaan kering untuk proses pewarnaan dan beri identitas dan tanggal pemeriksaan agar tidak tertukar (Gandasoebrata, 2010).

\section{Pewarnaan Sediaan}

Sedian yang sudah kering ditetesi larutan wright biarkan selama 20 menit, teteskan larutan buffer $\mathrm{pH}$ 6,4 ke atas sediaan biarkan 5-12 menit, kemudian bilas dengan aquadest secara perlahan-lahan dengan tujuan untuk mebuang zat warna yang terapung di atas 
sediaan. Letakkan preprat secara vertical dan biarkan kering di udara (Gandasoebrata, 2010).

HASIL DAN PEMBAHASAN

Hasil Berdasakan Jenis Kelamin

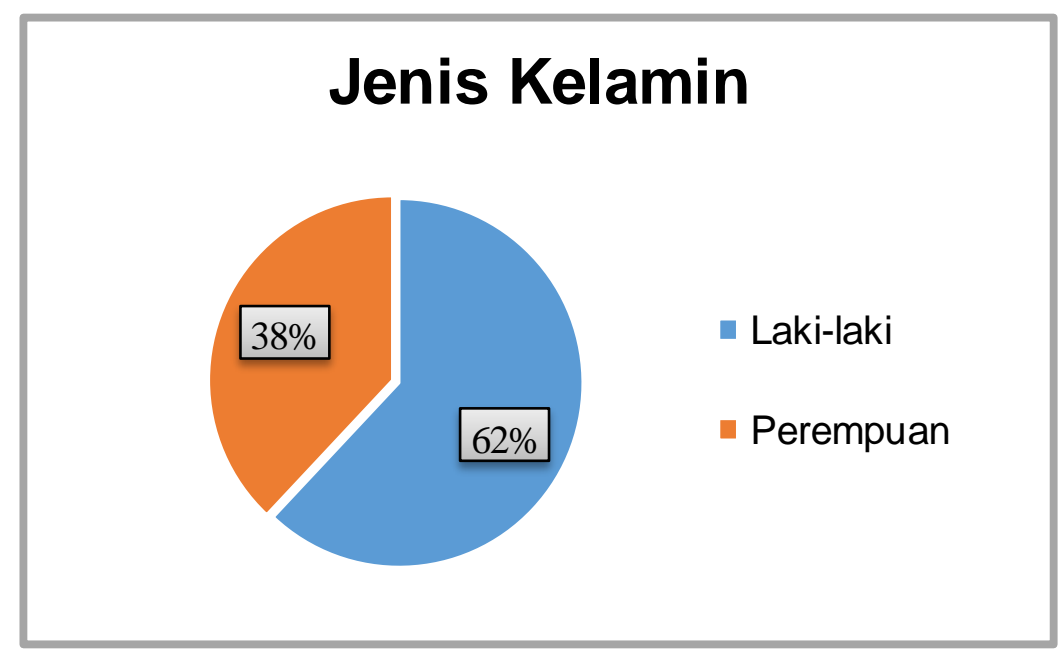

Gambar 1. Karakteristik Berdasarkan Jenis Kelamin

Hasil dari gambar 1 tersebut menunjukkan bahwa laki-laki lebih banyak menderita TB paru (62\%) dibandingkan dengan perempuan (38\%). Jumlah kejadian TB yang lebih besar terjadi pada laki-laki dapat disebabkan oleh aktivitas dan mobilitas yang tinggi dibandingkan perempuan sehingga potensi untuk terpapar lebih besar. Gaya hidup sehari-hari berupa konsumsi rokok dan alcohol juga dapat memudahkan laki-laki terinfeksi TB paru, hal ini sesuai dengan penelitian Dotulong dkk (2015).

\section{Hasil Berdasarkan Usia}

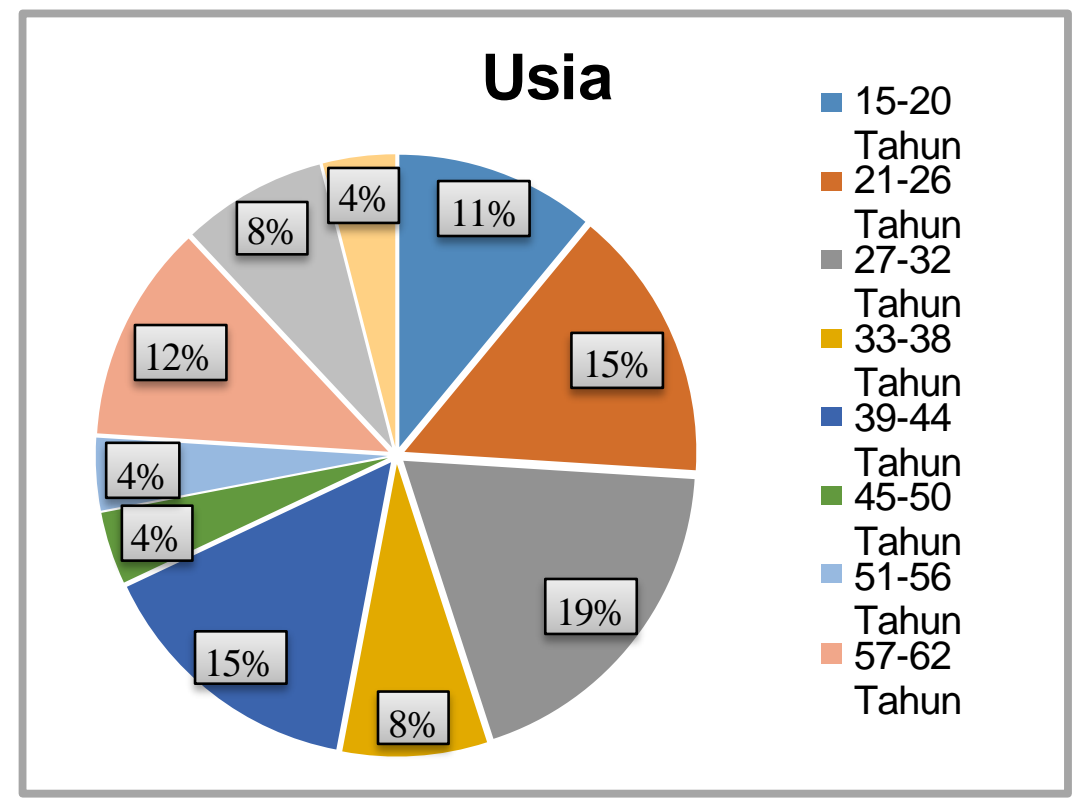

Gambar 2. Karakteristik Berdasarkan Usia 
Hasil gambar 2 menunjukkan bahwa usia responden menderita penyakit TB Paru terbesar adalah usia 27-32 tahun sebanyak 19\%, diikuti usia $21-26$ tahun sebanyak $15 \%$, usia 39-44 tahun sebanyak 15\%, 57-62 tahun sebanyak 12\%, usia 15-20 tahun sebanyak $11 \%$, 33-38 tahun sebanyak 8\%, usia 63-68 tahun sebanyak $8 \%, 45-50$ tahun sebanyak $4 \%$, usia $51-56$ tahun sebanyak $4 \%$, 75-80 tahun $4 \%$.

Usia yang paling produktif secara ekonomi 15 sampai 50 tahun menjadi penderita TB paru terbesar yang disebabkan tingginya aktivitas dan interaksi dengan banyak orang (Aditama,2011; Dotulong dkk, 2015. Kondisi kerja yang demikian ini memudahkan seseorang yang berusia produktif lebih mudah dan lebih banyak menderita TB paru. Hasil penelitian ini sejalan dengan penelitian Surento dkk (2017), adanya hubungan antara umur dan TB paru bahwa paling banyak terdapat umur produktif dimana pada umur produktif responden banyak melakukan aktifitas yang padat dan kondisi kerja yang kurang baik sehingga lebih rentan terpapar dengan bakteri Mycobacterium tuberculosis.

\section{Hasil Pemeriksaan Laboratorium}

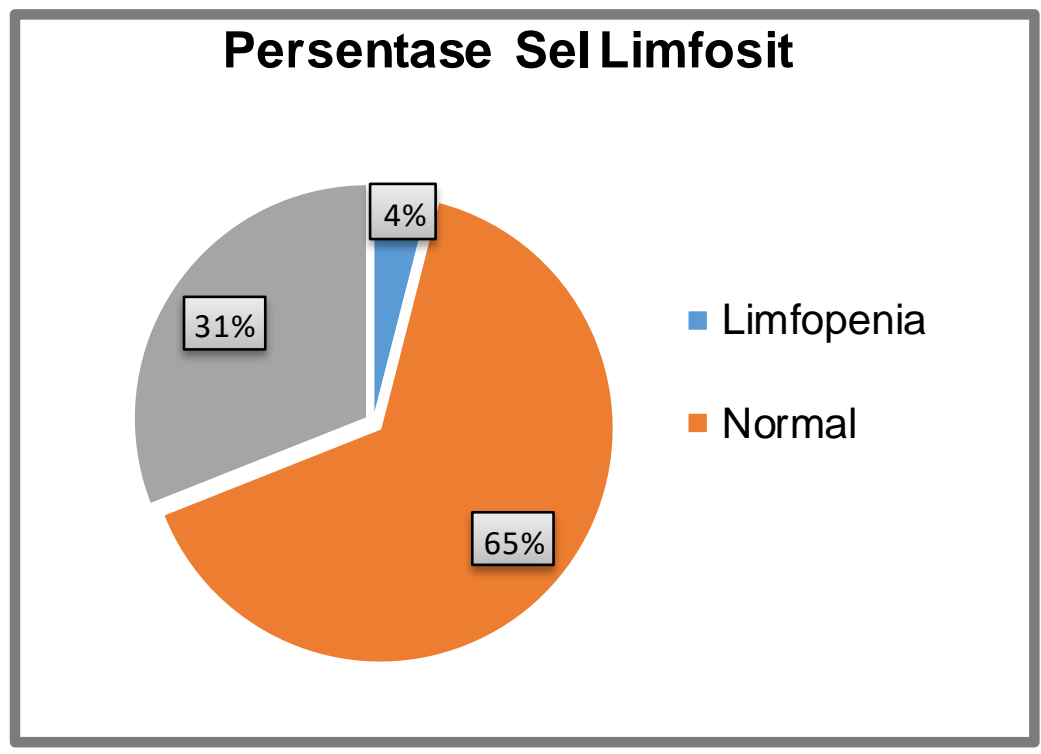

Gambar 3. Persentase sel limfosit

Hasil penelitian tentang gambaran pemeriksaan hapusan darah tepi sel limfosit pada penderita TB Paru di Pukesmas Kelayan Timur dengan jumlah 26 sampel didapatkan hasil pada gambar 3 menunjukkan responden yang memiliki mengalami limfopenia ada $4 \%$, responden dengan jumlah sel limfosit normal ada $65 \%$, dan responden yang mengalami jumlah limfositosis ada $31 \%$.

Pengobatan tuberkulosis paru yang berhasil, memperbaiki jumlah sel-sel limfosit menjadi normal, dimana saat bakteri tuberkulosis masuk kedalam tubuh terjadi penurunan jumlah limfosit yang menjukkan terjadinya infeksi dan menunjukkan proses TB aktif dan dengan adanya peran dari sistem imun pada penderita tuberkulosis membantu menghadapi infeksi bakteri dari tuberkulosis.

Infeksi Tuberkulosis memacu kerja dari limfosit T untuk aktivasi makrofag sehingga dapat lebih kuat dalam membuhuh bakteri, dimana makrofag yang telah aktif tersebut melepaskan interleukin-1 yang memacu limfosit $T$ sehingga limfosit $T$ melepaskan interleukin-2 yang merangsang limfosit $T$ lain untuk memperbanyak diri,matang dan memberi respon yang kuat pada antigen (Kaihena,2013).Limfopenia menunjukkan proses tuberkulosis aktif. Tuberkulosis yang aktif menyebabkan penurunan total limfosit $T$ sebagai akibat penurunan sel T4. Sel T8 tidak mengalami perubahan secara konsisten. Sel B total juga menurun.

Peningkatan jumlah limfosit atau limfositosis dapat menunjukkan adanya respon inflamasi terhadap bakteri penyebab penyakit TB dan menunjukkan adanya proses penyembuhan TB. 
Interleukin-2 yang telah merangsang limfosit $\mathrm{T}$ yang menjadi sel $\mathrm{T}$ reaktif terhadap Mycobacterium tuberculosis kemudian akan menghasilkan IFN, TNF, IL-2, IL-4, IL-5, IL-10 sama dengan sitokin yang dihasilkan oleh sel $\mathrm{T}$, selain itu supernatan dari sel $\mathrm{T}$ yang dirangsang oleh Mycobacterium tuberculosis akan meningkatkan agregasi makrofag dan selanjutnya berperan pada pembentukan granuloma. Makrofag yang teraktivasi menunjukkan peningkatan fungsi dalam fagositosis (Kaihena, 2013).

\section{KESIMPULAN}

Berdasarkan hasil penelitian yang telah dilakukan pada 26 pasien penderita TB paru di Puskesmas Kelayan Timur dapat disimpulkan bahwa pemeriksaan jumlah sel limfosit didapatkan hasil $<20 \%$ dengan persentase $4 \%$, hasil normal $20-40 \%$ sebanyak $65 \%$, dan $>40 \%$ sebanyak $31 \%$.

\section{DAFTAR PUSTAKA}

Aditama, T. Y \& Subuh, M. 2011. Pedoman Nasional Pengendalian Tuberkulosis. Jakarta : Kementrian Kesehatan RI.

Arianda, D. 2017. Buku Saku Analis Kesehatan (Revisi Ke-6). Bekasi : Analis Muslim Publishing.

Azizah, S. 2018. Hitung Jumlah Limfosit Dan Monosit Pada Pasien Tuberculosis Paru Yang Sedang Melakukan Pengobatan Di Puskesmas Poasia Anduonohu Kota Kendari. Karya Tulis IImiah. Politeknik Kesehatan Jurusan Analis Kesehatan. Kendari.

Dinas Kesehatan. 2018. Data Tuberkulosis Tahun 2017 : Banjarmasin.

Dotulong, J.F.J., Sapulete, M.R., Kandou, G.D. 2015. Hubungan Faktor Risiko Umur, Jenis Kelamin Dan Kepadatan Hunian Dengan Kejadian Penyakit Tb Paru Di Desa Wori Kecamatan Wori. Jurnal Kedokteran Komunitas dan Topik : Volume III 2 April 2015.

Gandasoebrata, S. 2010. Penuntun Laboraturium Klinik Cetakakn Keenam Belas. Jakarta : Dian Rakyat.

Kaihena, M. 2013. Propolis Sebagai Imunostimultor Terhadap Infeksi Micobacterium Tuberculosis.

Kementerian Kesehatan RI. 2017 . Tuberkulosis (TB), 1.

Notoatmodjo, S. 2012. Metodologi penelitian kesehata (Ed. Rev). Jakarta : Rineka Cipta.

Suciyani, N., Nurlia. A., \& Zulfian. 2017. Analisis Kuantitas Dan Hitung Jenis Leukosit Pada Petugas Radiologi Di Balai Besar Kesehatan Paru Masyarakat (Bbkpm) Makassar.

Rahmawati. 2013. Perbandingan Nilai Darah Rutin dan Berat Badan Anak Pada Pre dan Post 2 Bulan Terapi OAT di Rumah Sakit Khusus Paru-Paru Palembang. Karya Tulis IImiah. Universitas Muhammadiyah Palangkaraya.

Surento, I., Kaunang, W.P.J., Joseph, W.B.S. 2017. Hubungan Antara Umur, Kepadatan Hunian Dan Kebiasaan Merokok Dengan Kejadian Tubekulosis Paru Di Wilayah Kerja Puskesmas Paniki Bawah. 